\title{
Safety assessment of genetically modified crops for yield increase and resistance to both biotic and abiotic stresses and their impact on human and environment
}

\begin{abstract}
Biotechnology has now accelerated the breeding evolution of agricultural products to obtain stress-tolerant crops with improved productivity to meet the increasing global demand, which is in direct correlation with demographic trends. Nutritional quality, food allergies, toxicity effects, and unwanted resistance and alternations in gene sequences are the main concerns of genetically engineered products. Despite the numerous and overall benefits of genetically engineered crops, the questions raised by unwanted and unpredictable consequences about their safety concerns that may harm human, animal, and/or the ecosystem health require a long-term and a case-by-case transparent assessment before releasing the biotech crops into the food chain.
\end{abstract}

Keywords: Biotech crop; Genetically engineered; Risk assessment; Transgenic
Volume 8 Issue 2 - 2018

\author{
Omid Askari-Khorasgani,' Mohammad \\ Pessarakli² \\ 'Department of Horticultural Sciences, College of Agriculture \\ \& Natural Resources, Isfahan (Khorasgan) Branch, Islamic Azad \\ University, Iran \\ ${ }^{2} S$ chool of Plant Sciences, College of Agriculture and Life \\ Sciences, The University of Arizona, Tucson, USA
}

\author{
Correspondence: Mohammad Pessarakli, Editor-in-Chief, \\ Advances in Plants \& Agriculture Research, Professor, School \\ of Plant Sciences, College of Agriculture and Life Sciences, The \\ University of Arizona, Tucson, AZ 85721, USA, \\ Email: pessarak@email.arizona.edu
}

Received: October 20, 2017| Published: March 06, 2018

\begin{abstract}
Abbreviations: CaMV P35S, cauliflower mosaic virus 35S promoter; EFSA, European food safety authority; PGMO, panel on genetically modified organisms; ERA, environmental risk assessment; GE, genetically engineered; GM, genetically modified; GMO, genetically modified organism; GWAS, genome-wide association; HT, herbicide-tolerant; USDA, united states department of agriculture; Bt, Bacillus thuringiensis
\end{abstract}

\section{Introduction}

Due to the increase in the world population from the current 7.3 billion to more than 9.7 billion by 2050 United Nation World Population Prospects; ${ }^{1}$ World Population Forecast, ${ }^{2}$ and the predicted adverse effects of climate change Pachauri et al. ${ }^{3}$ Intergovernmental Panel on Climate, ${ }^{4}$ employing modern agriculture and biotechnology plays a key role in meeting global demands. However, the development and use of genetically modified (GM) crops raise safety concerns and their impact on both organisms and environment have remained controversial. To meet the global demand biotechnology has been employed worldwide to modify different crops such as cotton, maize, rice, canola and soybean Ahanger et al. ${ }^{5}$ In 2013, 93\% of the soybeans, $90 \%$ of the cotton, and $90 \%$ of the corn grown in the US were genetically engineered (GE) for either herbicide tolerance or insect resistance Economic Research Service. ${ }^{6}$ In 2016, Levitsky's test results for the long-term toxic effects, namely allergenicity, carcinogenicity, reproductive toxicity, and the possibility of mutagenic effects of these food products on the human body and the intestinal micro flora showed the absence of reliable scientific information indicating the presence of the toxic properties of genetically modified foods, and therefore of credible evidence of the dangers of consuming these foods by humans and pets Levitsky. ${ }^{7}$ The rapid development of cutting-edge biotechnologies such as direct gene editing by "CRISPRCas9" has also challenged the food regulation law. The United States Department of Agriculture (USDA) has determined that the current regulations are not suitable for several genome-edited crops, therefore, on November 18th, 2015, the USDA released provisional plans to revise its guidelines for GM crops Levitsky. ${ }^{7}$ Adoption of all GE cotton crops, taking into account the acreage with either or both herbicide-tolerant (HT) and bacterium Bacillus thuringiensis (Bt) traits, reached 93 percent of cotton acreage in 2016. The GE soybean adoption rates reached 94 percent in 2016 (soybeans have only HT varieties). Adoption of all GE corn accounted for 92 percent of corn acreage in 2016 Economic Research Service. ${ }^{6}$ Nonetheless, improving specific plant phenotypes through either mutagenesis in conventional breeding or transgenesis in GM crops may cause stress and weaken plant stress responses by altering the expression of untargeted genes Batista et al. ${ }^{8}$ Additionally, long variants of the cauliflower mosaic virus $35 \mathrm{~S}$ promoter (Ca MV P35S), which is used to drive the expression of transgenesis in genetically modified plants, for both research purposes and commercial applications do contain an open reading frame, when expressed, and might result in unintended phenotypic changes by encoding proteins with allergenic or toxic properties Podevin \& Du Jardin. ${ }^{9}$ These unintended changes in transgenic plants might lead to unpredictable chronic diseases and long-term toxicity of genetically modified organism (GMO) foods such as Roundup-tolerant genetically modified maize and soybean as reported by Séralini et al. ${ }^{10,11}$ Accordingly, this short review discusses 
both advantages and health risks of the GE crops to understand whether the safety assessments are still necessary with the current knowledge of biotechnology or because of its long time production and consumption history, it is unnecessary.

\section{Biotechnology benefits, limitations and consequences}

The main advantages of biotechnology in agriculture sector are producing tolerant crops to biotic and abiotic stresses. Optimization of crop performance under stress conditions can increase the economic value of crops and improve human, animal, and/or the environment health either by reducing the levels of pollutants such as synthetic fertilizers, herbicides, and pesticides Ahanger et al.; ${ }^{5}$ Sharma et al.; ${ }^{12}$ Gupta et al. ${ }^{13}$ Sharma et al. ${ }^{12}$ Singh ${ }^{14}$ or improving crop yield and quality such as improving the $\beta$-carotene in Gloden Rice Paine et al. ${ }^{15}$ Stein et al. ${ }^{16}$ Tang et al. ${ }^{17}$ Tang et al. ${ }^{18}$ However, to estimate the accurate impact of biotechnology on humans and the environment the challenges should also be taken into account. Corn (Zea mays L.) that has been GE to produce the Cry1 Ab protein ( $B t$ corn) is resistant to lepidopteron pests.

$B t$ corn is widely planted in the Midwestern United States, often adjacent to headwater streams. Corn by products, such as pollen and detritus, enter headwater streams and are subject to storage, consumption, and transport to downstream water bodies. Rosi-Marshall et al. ${ }^{19}$ findings showed that consumption of Bt corn byproducts reduced growth and increased mortality of Nontarget stream insects Rosi-Marshall et al. ${ }^{19}$ Stream insects are important prey for aquatic and riparian predators, and widespread planting of $B t$ crops has unexpected ecosystem-scale consequences. Rosi-Marshall et al. ${ }^{19}$ explained that, in a preliminarily laboratory experiment, caddis-fly larvae - herbivorous stream insects in the order trichoptera-fed only on $B t$ maize debris grew half as fast as those that ate debris from conventional maize. Also, caddis-flies fed high concentrations of $B t$ maize pollen died at more than twice the rate of caddis flies fed nonBt pollen.

The study concluded that transgenic maize "may have negative effects on the biota of streams in agricultural areas", stating in the abstract that "widespread planting of $B t$ crops has unexpected ecosystem-scale consequences" Rosi-Marshall et al. ${ }^{19}$ Although many questions have been raised after Rosi-Marshall et al. ${ }^{19}$ publication such as required comparisons between different GM and nonGM maize lines and dose dependent responses both in field and laboratory conditions Waltz ${ }^{20}$ still it is clear that $B t$ maize in their experiment could pose a threat to the environment. A small number of the ecotoxicology testing reports have so far raised concerns regarding the toxic effects and lower nutritional value of GM maize crops Rosi-Marshall et al. ${ }^{19}$ Bøhn et al. ${ }^{21}$;Schmidt et al..$^{22}$. Thus, long term experiments comprised of biotech and organic crops are still required to reach a convincing conclusion. In 2013, Gilbert published another report in Nature, indicating the rise of glyphosate-resistant weed species as a result of GMO evolution Gilbert ${ }^{23}$ In 2008, Philips published a report in Nature Education indicating that the vertical gene transfers between GMOs and their wild-type counterparts would not only put human health at risk, but also cause ecological imbalances Philips ${ }^{24}$. For instance, it may lead to a low viability of genetically modified fish offspring in a heritable manner Philips ${ }^{24}$. The potential, toxic effects and health risks of herbicides and GMO products have also been reported in several different experiments de
Vendômois et al.. ${ }^{25}$ Aris and Leblanc $;{ }^{26}$ Mesnage et al. $;{ }^{27}$ Séralini et al. ${ }^{10,28-30}$ It has been suggested that the debated alimentary chronic risks may come from unpredictable insertional mutagenesis effects, metabolic effects, or from the new pesticide residues de Vendômois et al..$^{25}$ In a 90-day experiment, GM corn MON863-treated rats caused growth variations and hepatorenal toxicity, hormone disturbance, the intensity of which were dependent on sex, duration, and concentration Séralini et al. ${ }^{10}$ In a two-year study, GM corn NK603-treated rats caused severe organ damage, particularly liver and kidney, increased the trend of tumours incidence, and reduced lifespan Séralini et al. ${ }^{29}$ Due to the higher GMO mutagenesis caused by tissue culture micropropagation processes like somaclonal variation and endogenous DNA rearrangements, recombination, and high molecular DNA insertions, the GE plant gene sequences might be unpredictable and unstable Mertens; ${ }^{31}$ Maghari \& Ardekani ${ }^{32}$. Thus, based on the longterm effects on the whole ecosystem in different field conditions and because of the unpredictable changes in organisms (e.g., affecting unwanted resistance and gene sequences as well as non-targeted genes and organisms) the risk assessment of biotech crops and changes in agrochemical inputs and crop performance should be evaluated prior to commercialization.

\section{Safety assessments}

Despite the rapid biotechnological improvements, at this time and with the current knowledge, safety and risk assessments of GE plants, there are sufficient scientific data enabling qualitative/quantitative risk estimates required for both human and the environment (crops, weeds, animals, namely fish, insects, such as pollinisers, mammals, and birds). This is similar to the environmental risk assessment (ERA) of the living GM animals and should be carried out on a case-bycase basis and not simply restricted to foods obtained through genetic engineering [European Food Safety Authority Panel on Genetically Modified Organisms EFSA GMO Panel ${ }^{33}$. Despite the concerns about the GM crops, the necessity of biotechnology for crop improvement is still undeniable. In addition to promoting crop yield and resistance to multiple biotic and abiotic stresses, biotechnology can be employed to improve plant quality such as nutrition and its market acceptability. According to Tieman et al. ${ }^{34}$ whole-genome sequencing and a genomewide association (GWAS) can be employed for the identification of genetic loci that affect quantitative traits such as the target flavour chemicals, including sugars, acids, and volatiles, which are necessary for the recovery of traits ignored in modern commercial varieties Tieman et al. ${ }^{34}$ In this context, the Russian Federation has released the principles of safety assessments which cover

a. Molecular assessment,

b. Human health safety assessment,

c. Technological parameters,

d. Assessment of the data presented by the applicant on the examined GMO (Russian Federation, 2013). Taken together, a transparent and truthful risk-benefit analysis on a case-by-case basis would create a positive impact on marketability and agricultural values of GMOs.

\section{Conclusion}

Development in technologies based on the CRISPR/Cas9 has less-off target effects and allows more precise gene editing. However, 
different tools of biotechnology are currently being deployed worldwide and their long-term effects on organisms and ecosystem health are unpredictable. Hence, transparent safety assessments on a case-by-case basis increase the value of biotech products and avoid their unwanted consequences.

\section{Acknowledgment}

The authors sincerely appreciate the Editorial Team of the Advances in Plants \& Agriculture Research (APAR), particularly, the Executive/Managing Editor, Dr. Rebecca Miller for diligently handling this manuscript

\section{Conflict of interest}

There is no conflict of interest in this review article.

\section{References}

1. United Nation World Population Prospects. United Nation World Population Prospects. 2015.

2. World Population Forecast. World Population Forcast. 2016.

3. Pachauri RK, Allen MR, Barros VR, et al. Climate change 2014: synthesis report. Contribution of Working Groups I, II and III to the fifth assessment report of the Intergovernmental Panel on Climate Change 2014; p.151

4. Intergovernmental Panel on Climate C. Climate Change 2014: Mitigation of Climate Change: Working Group III Contribution to the IPCC Fifth Assessment Report. Cambridge University Press, Cambridge. 2015.

5. Ahanger MA, Akram NA, Ashraf M, et al. Plant responses to environmental stresses-from gene to biotechnology. AoB Plants. 2017;9(4):plx025.

6. Economic Research Service. Adoption of Genetically Engineered Crops in the US, Recent Trends in GE Adoption, Department of Agriculture, USA. 2013.

7. Levitsky E. Problem of genetically modified foods safety: a toxicologist's view. Biotechnologia Acta. 2016;9(1):7-25.

8. Batista R, Saibo N, Lourenço T. Microarray analyses reveal that plant mutagenesis may induce more transcriptomic changes than transgene insertion. Proceedings of the National Academy of Sciences. 2008;105(9):3640-3645.

9. Podevin N, du Jardin P. Possible consequences of the overlap between the CaMV 35S promoter regions in plant transformation vectors used and the viral gene VI in transgenic plants. GM Crops \& Food. 2012;3(4):296-300.

10. Séralini GE, Cellier D, de Vendomois JS. New analysis of a rat feeding study with a genetically modified maize reveals signs of hepatorenal toxicity. Archives of Environmental Contamination and Toxicology. 2007;52(4):596-602.

11. Séralini GE, Clair E, Mesnage R, Republished study: long-term toxicity of a Roundup herbicide and a Roundup-tolerantgenetically modified maize. Environmental Sciences Europe. 2014a;26(1):14.

12. Sharma R, Srivastva R, Shukla K, et al. Environmental Control of Biotechnology Industries, In: Singh RL. editor, Principles and Applications of Environmental Biotechnology for a Sustainable Future. Springer Singapore, Singapore, 2017.pp.365-391.

13. Gupta V, Sengupta M, Prakash J, et al. Environmental Biotechnology, In: Gupta V, Sengupta M, et al. editors, Basic and Applied Aspects of Biotechnology. Springer Singapore, Singapore, 2017;pp.385-413.
14. Singh RL. Introduction to Environmental Biotechnology, In: Singh RL. editor, Principles and Applications of Environmental Biotechnology for a Sustainable Future. Springer Singapore, Singapore,2017.pp.1-12.

15. Paine JA, Shipton CA, Chaggar S, et al. Improving the nutritional value of Golden Rice through increased pro-vitamin A content. Nature Biotechnology. 2005;23(4):482-487.

16. Stein AJ, Sachdev HP, Qaim M. Potential impact and costeffectiveness of Golden Rice. Nature Biotechnology. 2006;24(10): $1200-1201$.

17. Tang G, Qin J, Dolnikowski GG et al. Golden Rice is an effective source of vitamin A. Am J Clin Nutr. 2009;89(6):1776-1783.

18. Tang G, Hu Y, Yin SA, et al. $\beta$-Carotene in Golden Rice is as good as $\beta$-carotene in oil at providing vitamin $\mathrm{A}$ to children. The American Journal of Clinical Nutrition. 2012;96(3):658-664.

19. Rosi-Marshall EJ, Tank JL, Royer TV, et al. Toxins in transgenic crop byproducts may affect headwater stream ecosystems. Proceedings of the National Academy of Sciences. 2007;104(41):16204-16208.

20. Waltz E. GM crops: Battlefield. Nature, 2009;461(7260):27-32.

21. Bøhn T, Primicerio R, Hessen DO, et al. Reduced Fitness of Daphnia magna Fed a Bt-Transgenic Maize Variety. Arch Environ Contam Toxicol. 2008;55(4):584-592.

22. Schmidt JEU, Braun CU, Whitehouse LP, et al. Effects of Activated $\mathrm{Bt}$ Transgene Products (Cry1 Ab, Cry3Bb) on Immature Stages of the Ladybird Adalia bipunctata in Laboratory Ecotoxicity Testing. Arch Environ Contam Toxicol. 2009;56(2):221-228.

23. Gilbert N. Case studies: A hard look at GM crops. Nature. (2013);497(7447):24-26.

24. Phillips T. Genetically modified organisms (GMOs): Transgenic crops and recombinant DNA technology. Nature Education. 2008;1(1):213

25. de Vendômois JS, CellierD, VelotC, et al. Debate on GMOs health risks after statistical findings in regulatory tests. Int J Biol Sci. 2010;6(6):590-598.

26. Aris A1, Leblanc S. Maternal and fetal exposure to pesticides associated to genetically modified foods in Eastern Townships of Quebec, Canada. Reproductive Toxicology. 2011;31(4):528-533.

27. Mesnage R, Moesch C, Grand RLG, et al. Glyphosate exposure in a farmer's family. Journal of Environmental Protection. 2012;3(9):1001-1003.

28. Séralini GE, de Vendômois JS, Cellier D, et al. How subchronic and chronic health effects can be neglected for GMOs, pesticides or chemicals. International Journal of Biological Science. 2009;5(5):438-443.

29. Séralini GE, Mesnage R, Defarge N, et al. Conflicts of interests, confidentiality and censorship in health risk assessment: the example of an herbicide and a GMO. Environmental Sciences Europe. 2014b;26(1):13

30. Séralini GE, Mesnage R, Defarge N, et al. Conclusiveness of toxicity data and double standards. Food and Chemical Toxicology. 2014c;69:357-359.

31. Mertens M. Assessment of environmental impacts of genetically modified plants. Implementation of the Biosafety Protocol Development of Assessment Bases. FKZ 20167 430/07. BfNSkripten 217 (Bundesamt fur Naturschutz). 2008;p.234.

32. Maghari BM, Ardekani AM. Genetically Modified Foods and Social Concerns. Avicenna J Med Biotechnol. 2011;3(3):109-117. 
33. European Food Safety Authority Panel on Genetically Modified Organisms (EFSA GMO Panel). Guidance on the environmental risk assessment of genetically modified animals. EFSA Journal. 2013;11(5):3200-3190.

34. Tieman D, Zhu G, Resende MFR, et al. A chemical genetic roadmap to improved tomato flavor. Science. 2017;355(6323):391-394.
35. Russian Federation. Chapter 4-Principles of Human Health Safety Assessment of Genetically Modified Plants Used in the Russian Federation A2, In: Tutelyan VA. editor, Genetically Modified Food Sources. Academic Press, San Diego, 2013;p.31-42. 